\title{
A Bridge Too Far? Assessing the Prospects for International Environmental Law to Resolve the South China Sea Disputes
}

\section{DAVID M. ONG*}

\section{Introduction}

Doctrinal approaches to the territorial and maritime jurisdiction disputes of the South China Sea have traditionally resorted to the consideration of the international law on acquisition of territorial sovereignty or title over the islands, rocks or low-tide elevations within this semienclosed sea, and the international law of the sea, in seeking resolutions to these disputes. However, neither of these two substantive fields of international law has proved successful to date in settling these disputes before an international court or tribunal and, as Hayton notes, "given the complexity and uncertainty of the intersecting legal difficulties, it seems unlikely that they ever will." The present analysis thus proceeds on the basis that, at least in the short term, the international legal differences between the various different claimant states in the South China Sea are arguably intractable. Acknowledgement of these currently insurmountable differences paves the way for consideration of other, related but less historically and politically significant international legal developments to be taken into account when establishing the legal constraints around the activities undertaken on and around many of the insular formations found in the South China Sea. In this paper, the potential for international environmental law to resolve the South China Sea disputes will be examined. Specifically, the development of procedural international obligations initially applicable to 'shared' water bodies and natural resources, and progressively extending to overall environmental protection, will be assessed. These procedural international obligations will be mapped onto the South China Sea disputes, with a view to assessing the potential for such obligations to provide the means for co-operation towards the resolution of these disputes.

Before the legal analysis begins, it is useful to chart the geographical aspects of the South China Sea disputes to better understand how these factors inform the international legal issues raised by them. Beckman has provided a succinct description of the South China Sea:

"The South China Sea is a semi-enclosed sea bordered on the west by Vietnam, on the east by the Philippines, Malaysia, and Brunei Darussalam, on the south by Indonesia and Malaysia, and on the north by China and Taiwan. The width of the South China Sea is approximately 550-650 nautical miles $(\mathrm{nm})$, and its length is more than $1200 \mathrm{~nm} .{ }^{\prime 2}$

As for the number and different types of insular formations found in this semi-enclosed sea, according to Buszynski:

"Estimates of the number of features in the South China Sea vary considerably because of the difficulty of distinguishing between islands, atolls and reefs, many of which are only visible in low tide. Some estimate the number at 190 islets, still others opt for the general figure of 400 rocks, reefs, and islands, other estimat es range as high as 650 . Figures on the number of occupied islands for this reason vary and range from $48-50$.

\footnotetext{
* Professor of International and Environmental Law, Nottingham Law School, Nottingham Trent University, UK. E-mail: davidm.ong@ntu.ac.uk.

${ }^{1}$ B. Hayton, The South China Sea: The Struggle for Power in Asia (Yale University Press, New Haven, 2014) p 99.

${ }^{2}$ R. Beckman, 'The UN Convention on the Law of the Sea and the Maritime Disputes in the South China Sea', 107 American Journal of International Law (2013) p. 143.
} 
The term occupation is ambiguous as some islands may have a permanent garrison while small atolls may be garrisoned for part of the year; others may have only a token presence and still be called 'occupied'."3

\section{South China Sea Disputes: International Legal Issues}

The two main sets of legal issues arising from the South China Sea disputes revolve around first, neighbouring coastal state assertions of territorial sovereignty or title over the various insular formations located in the South China Sea, relying on the accepted modes of acquisition of such sovereignty/title under international law; and second, the consequential claims of maritime jurisdiction zones - territorial sea, exclusive economic zones (EEZs) and continental shelves - that derive from territorial sovereignty/title over these islands, rocks or low-tide elevations. ${ }^{4}$ On the first set of issues, Sumner has enumerated nine different categories of claims used by states to justify their sovereignty/title over territory before the International Court of Justice (ICJ), with the most common legal arguments "cast in terms of effective control of the disputed territory, historical right to title, uti possidetis, geography, treaty law, and cultural homogeneity." ${ }^{5}$ On the second set of issues, as Beckman notes:

"Brunei Darussalam, China, Malaysia, the Philippines, and Vietnam are the claimant states that have competing claims to territorial sovereignty over the islands in the South China Sea. UNCLOS does not address questions of sovereignty over land territory. Its provisions on coastal state jurisdiction assume such sovereignty. The coastal states have also made overlapping, conflicting claims to jurisdiction over the South China Sea itself." 6

Focussing on the different international legal implications of the nature of the insular formations in the South China Sea, the definition of an 'island' is found in Article 121 of the UNCLOS, which states that "an island is a naturally formed area of land, surrounded by water, which is above water at high tide." An island thus defined can generate a territorial sea of up to a breadth of 12 nautical miles (nm) and a contiguous zone up to $24 \mathrm{~nm}$ from the island's baselines, as well as an exclusive economic zone (EEZ) of 200nm and a continental shelf as defined by Article 76, the outermost limits of which can reach $350 \mathrm{~nm}$ or $100 \mathrm{~nm}$ from the 2,500 meter $(\mathrm{m})$ isobath, which is the line delineating every point at the depth of $2,500 \mathrm{~m}$. On the other hand, according to Article 121(3), rocks 'which cannot sustain human habitation or economic life of their own shall have no exclusive economic zone or continental shelf', although they can be used as base points in the sea from which to draw the outer limits of all other maritime jurisdiction zones. Finally, 'low-tide elevations', which are defined by Article 13(1) as surrounded by and above water at low tide but submerged at high tide, can only be used as a base point for measuring the breadth of the territorial sea if located at a distance not exceeding the breadth of the territorial sea from the mainland or an island. The international legal significance of being able to claim that a 'rock' or 'low-tide elevation' is now an 'island', in terms of the full suite of maritime jurisdiction zones generated from islands, forms the basis for much of the state activities on these insular formations to date.

The main types of state activity being undertaken to 'shore' up the territorial sovereignty claims of neighbouring claimant states in the region generally involve land reclamation projects, the construction of artificial islands, research posts, observation towers, helipads and other buildings or installations on various insular formations in the South China Sea. For example, recent satellite imagery has identified Chinese land reclamation activity and the

\footnotetext{
${ }^{3}$ L. Buszynski, 'Rising Tensions in the South China Sea: Prospects for a Resolution of the Issue', 6 Security Challenges (2010) p. 85.

${ }^{4}$ Hayton, supra note 1, p. 92 .

${ }^{5}$ B. T. Sumner, 'Territorial Disputes at the International Court of Justice', 53 Duke Law Journal (2004) p. 1780.

${ }^{6}$ Beckman, supra note 2, p. 142.
} 
construction by China of a new facility on Hughes Reef in the Spratly Islands. The site has been expanded from a 380 square meter (sq $\mathrm{m}$ ) platform to an artificial 'island' that is now $75,000 \mathrm{sq} \mathrm{m}$. The original $380 \mathrm{~m}^{2}$ installation remains, surrounded by reclaimed land in a manner consistent with other Chinese reclamation projects in the South China Sea. Similar satellite imagery also shows the progress of construction at Gaven Reefs, with a causeway linking the newly constructed artificial island to the original facility and the construction of a helipad. Commenting on these new and extended constructions, O'Connor and Hardy note that the buildings on Hughes Reef and Gaven Reefs have almost identical footprints: that of a main square building with what appears to be an anti-aircraft tower or radome at each corner. They suggest that China has standardized the design of key facilities and is rolling it out across its new 'islands'. ${ }^{7}$ As evidence of these new activities grows, so have the diplomatic protests against them by other claimant states in the South China Sea, although as Tran points out, all the claimant states, with the sole exception of Brunei, have engaged in different kinds of constructions on the island/rock/low-tide elevations that they 'control'. ${ }^{8}$

On the other hand, an arguably more subtle approach to the issue of the international legal implications of these 'islands' can be discerned from the enactment by the Philippines of a new law on archipelagic baselines that specifically cites Article 121 of UNCLOS as the basis for the declaration of a 'regime of islands' for the land features in the South China Sea, including the so-called 'Kalayaan Island Group' and Scarborough Shoal, that the Philippines have claimed. ${ }^{9}$ According to Severino, the enactment of the new law was a clear attempt to render the Phillipine claims in the area adjacent to its archipelago more consistent with UNCLOS provisions, while preserving a degree of ambiguity by not indicating which of the land features that it claims are 'islands' as defined in Article 121, which can generate continental shelves and exclusive economic zones, and which are 'rocks', which cannot. ${ }^{10}$

Within the maritime jurisdiction zones generated from these so-called 'islands', the two main types of natural resource-based activities that are being sanctioned by the different claimant states in the South China Sea region are as follows: First, the award of licences and concessions for offshore oil and gas exploration in disputed continental shelf areas; and second, the permitting or licensing of fishery activities in the exclusive economic zones (EEZs) from both mainland and insular coastlines in the South China Sea. Associated resource-based activities that are undertaken either by governments, state-owned companies, or private companies under government license, include the placement of oil/gas drilling rigs/platforms/installations in such disputed continental shelf/EEZ areas. As might be expected, both types of activities are the subject of diplomatic protests by other claimant states and other actions denying the exercise of such sovereign rights and maritime jurisdiction within the disputed areas of the South China Sea.

\footnotetext{
7 'Imagery shows progress of Chinese land building across Spratlys', by S. O'Connor and J. Hardy, IHS Jane's Defence Weekly, 15 February, 2015. <http://www.janes.com/article/48984/imagery-shows-progress-of-chineseland-building-across-spratlys >, visited on 27 April 2015.

${ }^{8}$ T. T. Thuy, 'Construction in the South China Sea: A Comparative View', Asian Maritime Transparency Initiative Website http://amti.csis.org/construction-in-the-south-china-sea-a-comparative-view/>, visited on 27 April 2015. 9 Republic Act, 3522, adopted on $10 \quad$ March, 2009. http://www.lawphil.net/statutes/repacts/ra2009/ra_9522_2009.html>, visited on 27 April 2015.

${ }^{10}$ R. C. Severino, 'Cooperation for Regional Security and Development in the South China Sea', in T. T. Thuy (ed), The South China Sea Towards A Region of Peace, Security and Cooperation, (Thế Giới Publishers, Hanoi, 2011) p. 323.
} 


\section{Alternative International Law Developments Applicable to the South China Sea Disputes}

Regardless of the relative strengths of the competing claims by the littoral states, the prospects for the international legal resolution of the territorial and maritime jurisdiction disputes of the South China Sea remain elusive. This is mainly due to the lack of a compulsory international dispute settlement procedure that is legally binding on all potential state claimants. To begin with, none of these states have accepted the compulsory jurisdiction of the International Court of Justice (ICJ) in relation to the legal resolution of these disputes. While all the claimant states are parties to the 1982 UNCLOS, possible recourse under Part XV of this Convention suffers from at least two difficulties: First, the type of disputes that can be brought before the dispute settlement procedures under Part XV are limited to the 'interpretation or application of this Convention. ${ }^{11}$ As previously observed, this Convention does not cover the international law on acquisition of territorial sovereignty. Specifically, Article 298(a)(i) provides that maritime boundary issues and any dispute that necessarily involves the concurrent consideration of sovereignty or other rights over continental or insular land territory shall be excluded from the compulsory, judicial procedures under Part XV of UNCLOS. This means that the South China Seas disputes, involving territorial sovereignty over islands/rocks and the maritime jurisdiction zones that these islands/rocks can generate, are arguably excluded from submission to the international judicial bodies referred to in Part XV of the 1982 UNCLOS. This is essentially the argument of the People's Republic of China (PRC) in its denial of the admissibility of the claims brought by the Philippines against China and jurisdiction of the Annex VII arbitral tribunal established to hear these claims, as discussed further below. Second, while recourse may be had to the 1975 Treaty of Amity and Co-operation in Southeast Asia for regional disputes between the Association of Southeast Asian Nations (ASEAN) states, to which China became a party in 2003 , the fact remains that these dispute settlement procedures are not judicial in nature, and neither compulsory, nor binding on the parties involved.

In contrast, international law has made significant developments in other areas that are ripe for application to the South China Sea disputes. These international legal developments were initially in the fields of common water bodies and shared natural resources and latterly, in the form of international environmental law. The rest of this section will focus on these procedural rules of co-operation for shared natural resources and environmental protection, as initially enunciated in relevant early international case law, confirmed in subsequent multilateral conventions, and elaborated in later international case law.

\subsection{Procedural Obligations in the International Law of Common Water Bodies and Shared Natural Resources}

The Lac Lanoux case (1957) ${ }^{12}$ before an international arbitral tribunal, contains an early iteration of these obligations. In this case, France applied to divert the waters of the Lac Lanoux for electricity generation purposes. Responding to claims that such a diversion would harm Spanish interests, the tribunal noted that:

"A State wishing to do that which will affect an international watercourse cannot decide whether another State's interests will be affected; the other State is the sole judge of that and has the right to information on the proposals. Consultations and negotiations between the two States must be genuine, must comply with the

\footnotetext{
${ }^{11}$ Article 297, UNCLOS 1982.

${ }^{12}$ Lac Lanoux Arbitration (France v. Spain), 12 RIAA p. 281; 24 I.L.R. p. 101. Unofficial English translation of Award accessible at: <http://www.ecolex.org/server2.php/libcat/docs/COU/Full/En/COU-143747E.pdf〉.
} 
rules of good faith and must not be mere formalities. The rules of reason and good faith are applicable to procedural rights and duties relative to the sharing of the use of international rivers."13

These procedural requirements of notification, information, consultation and negotiations in good faith applied by the Lac Lanoux tribunal under customary international law have now been codified in the form of the 1997 Convention on the Law of the Non-navigational Uses of International Watercourses. ${ }^{14}$ Following an enunciation of the "general obligation to cooperate" under Article 8, Article 12 entitled "[n]otification concerning planned measures with possible adverse effects", can be summarized as follows: prior to a watercourse state's implementation of planned measures which may have a significant adverse effect upon other watercourse states, it shall provide those states with timely notification thereof, including, inter alia, the results of any environmental impact assessment, in order to enable the notified states to evaluate the possible effects of the planned measures. Moving from shared freshwater water bodies to their saltwater equivalents, namely, enclosed and semi-enclosed seas, as defined under Article 122 of UNCLOS, both Articles 204 and 206 apply similar articulations of these obligations. Article 204 provides inter alia that states shall monitor the risks or effects of pollution of the marine environment and keep under surveillance the effects of any activities which they permit or in which they engage in order to determine whether these activities are likely to pollute the marine environment. Article 206 then notes that:

"[W]hen States have reasonable grounds for believing that planned activities under their jurisdiction or control may cause substantial pollution of or significant and harmful changes to the marine environment, they shall, as far as practicable, assess the potential effects of such activities on the marine environment and shall communicate reports of the results of such assessments."

\subsection{Procedural Obligations in International Environmental Law}

Moving on to the contribution of the International Court of Justice (ICJ) to this developing field of international law, the Pulp Mills case $(2010)^{15}$ is at least in part about the extent of the duty between neighbouring states to notify, inform and consult each other about proposed activities that have potentially serious transboundary environmental impacts. In this case concerning objections by Argentina over the building of two pulp mills by Uruguay across the water from a shared river boundary between these two states, the ICJ first noted that "the obligation to notify is intended to create the conditions for successful co-operation between the parties, enabling them to assess the plan's impact on the river on the basis of the fullest possible information and, if necessary, to negotiate the adjustments needed to avoid the potential damage that it might cause." 16 The Court concluded that "the obligation to notify is therefore an essential part of the process leading the parties to consult in order to assess the risks of the plan and to negotiate possible changes which may eliminate those risks or minimize their effects." 17

The ICJ ruled that "it may now be considered a requirement under general international law to undertake an environmental impact assessment (EIA) where there is a risk that the proposed industrial activity may have a significant risk in a transboundary context, in particular, on a shared resource." 18 The Court noted that "the environmental impact assessments which are

13 Ibid.

${ }^{14}$ Adopted in New York, on 21 May, 1997. <http://legal.un.org/avl/ha/clnuiw/clnuiw.html>, visited on 27 April 2015.

${ }^{15}$ Case Concerning Pulp Mills on the River Uruguay (Argentina v. Uruguay), 20 April, 2010. ICJ, Judgment, <http://www.icj-cij.org/docket/files/135/15877.pdf>, visited on 27 April 2015

${ }^{16}$ Ibid., para. 113

${ }^{17}$ Ibid., para. 115

${ }^{18}$ Ibid, para.204. 
necessary to reach a decision on any plan that is liable to cause significant transboundary harm to another State must be notified by the party concerned to the other party, ... to enable the notified party to participate in the process of ensuring that the assessment is complete, so that it can then consider the plan and its effects with a full knowledge of the facts." 19 The Court then observed that this notification must take place before the state concerned decides on the environmental viability of the plan, taking due account of the environmental impact assessment submitted to it. ${ }^{20}$ The Court concluded that Uruguay had failed to fulfil her procedural obligation to notify and allow Argentina to participate in the transboundary EIA exercise prior to approving the proposed projects. ${ }^{21}$

However, the Court also observed that general international law does not specify the scope and content of an environmental impact assessment. Consequently, it is for each state to determine in its domestic legislation or in the authorization process for the project, the specific content of the environmental impact assessment required in each case, having regard to the nature and magnitude of the proposed development and its likely adverse impact on the environment as well as to the need to exercise due diligence in conducting such an assessment. ${ }^{22}$ Finally, the Court considered that once operations have started and, where necessary, throughout the life of the project, continuous monitoring of its effects on the environment shall be undertaken. ${ }^{23}$

Apart from the binding decisions (for the states involved) of the judicial decisions above, the Seabed Disputes Chamber of the International Tribunal on the Law of the Sea (ITLOS) has also rendered an authoritative, albeit non-legally binding Advisory Opinion $(2011)^{24}$ on the applicable international law and especially, international environmental law principles applicable to the states that oversee the activities of legal persons or entities within the deep sea-bed area, beyond the limits of national jurisdiction. Among the most important of these direct obligations incumbent on sponsoring states are as follows: the obligation to assist the Authority in the exercise of control over activities in the Area; the obligation to apply a precautionary approach; the obligation to apply best environmental practices; the obligation to take measures to ensure the provision of guarantees in the event of an emergency order by the Authority for protection of the marine environment; the obligation to ensure the availability of recourse for compensation in respect of damage caused by pollution; and the obligation to conduct environmental impact assessments. ${ }^{25}$ The Chamber stressed that the obligation to conduct an environmental impact assessment is a direct obligation under the 1982 UNCLOS and a general obligation under customary international law, ${ }^{26}$ reiterating both article 206 of the Convention, ${ }^{27}$ and referring directly to paragraph 204 of the Pulp Mills judgment (both cited above). ${ }^{28}$ Significantly for our purposes in arguing for the application of these procedural obligations in the South China Sea, the Chamber noted that:

"Although aimed at the specific situation under discussion by the Court, the language used seems broad enough to cover activities in the Area even beyond the scope of the Regulations. The Court's reasoning in a transboundary context may also apply to activities with an impact on the environment in an area beyond the

${ }^{19}$ Ibid., para.119.

${ }^{20}$ Ibid., para. 120

${ }^{21}$ Ibid., para. 122

${ }^{22}$ Ibid., para.205.

23 Ibid.

${ }^{24}$ Responsibilities and Obligations of States Sponsoring Persons and Entities with respect to Activities in the 'Area', 1 February 2011, Seabed Disputes Chamber of the ITLOS, Advisory Opinion. <http://www.itlos.org>, visited on 27 April 2015.

${ }^{25}$ Ibid., para. 122.

${ }^{26}$ Ibid., para. 145.

${ }^{27}$ Ibid., para. 146.

${ }^{28}$ Ibid., para. 147. 
limits of national jurisdiction; and the Court's references to 'shared resources' may also apply to resources that are the common heritage of mankind." 29

Summarising the implications of this conjunction between relevant UNCLOS treaty provisions and international tribunal jurisprudence for the South China Sea disputes, Beckman notes that UNCLOS State party obligations to protect the marine environment arise from their 'jurisdiction and control' over their activities within, rather than on the basis of their sovereignty over these disputed insular features and associated maritime zones. ${ }^{30}$ Moreover, their 'jurisdiction and control' over these activities has to fulfil the due diligence requirement, which he characterises as an obligation of conduct, not of result. ${ }^{31}$ Enlarging on the required conduct to fulfil the due diligence test, Beckman cites the requirement to monitor activities within the 'jurisdiction and control' of the UNCLOS State parties, the requirement to cooperate with neighbouring States that share interests in these activities, and the corollary duty to both these requirements in the form of the duty to conduct an EIA. ${ }^{32}$

Thus, it is possible to distil at least two requirements that apply erga omnes to all neighbouring and other states with interests in this region, whether territorial, resource, or freedom of navigation-based. These can be summarized as follows:_First, there is a duty to inform and consult other interested states over all planned activities that may have implications for their sovereign rights and exercise of jurisdiction in the disputed region, whether these are marine-based research and/or exploration activities, or building activities on any insular formations._Second, there is a duty to conduct an EIA for such activities, including addressing the possible impacts on freedom of navigation and ecological/environmental concerns.

\subsection{Specific Procedural Obligations for Shared Hydrocarbon Resources}

Moving from the general obligations for planned activities with environmental implications in the context of a shared natural resource such as a common international river, the deep seabed beyond national jurisdiction, or a semi-enclosed sea like the South China Sea, to the specific obligations relating to common, transboundary, or otherwise shared, hydrocarbon resources, we find that international tribunal jurisprudence has also confirmed the need for certain procedural obligations to be adhered to. For example, the specific issue of licensing offshore oil and gas exploration activities was subject to judicial scrutiny in the Guyana/Suriname case (2007). ${ }^{33}$ In this case, an UNCLOS Annex VII arbitral tribunal prescribed a negotiation process involving detailed notification, information disclosure and consultation requirements for the State initiating offshore hydrocarbon exploration activities within an area of overlapping continental shelf claims, based on Article 83(3) of the 1982 UNCLOS.

Assessing Guyana's actions as the State that initiated the exploration activities in the disputed maritime area, the arbitral tribunal ruled that Guyana had violated its obligations under the relevant Article. In relation to the first, co-operative, obligation to make every effort to enter into provisional arrangements, the Tribunal placed a specific obligation upon Guyana to inform Suriname directly of her plans to allow its concessionaire/licensee, CGX to undertake

\footnotetext{
${ }^{29}$ Ibid., para.148 (emphasis added).

${ }^{30}$ R. Beckman, 'International Law and China's Reclamation Works in the South China Sea', paper presented at the $2^{\text {nd }}$ Conference on South China Sea, Centre on Asia and Globalisation, Lee Kuan Yew School of Public Policy, National University of Singapore, and Collaborative Innovation Centre for South China Sea Studies, Nanjing University, April 24-25, 2015.16pp, at p.9. Accessible from:

31 Ibid., at p. 10.

32 Ibid., at pp.11-12.

${ }^{33}$ Guyana v. Suriname, 17 September 2007, UNCLOS Annex VII Arbitral Tribunal Award, <http://www.pcacpa.org/showpage.asp?pag_id=1147>, visited on 27 April 2015.
} 
exploratory drilling, noting further that 'notification in the press by way of CGX's public announcements was not sufficient for Guyana to meet its obligation under articles 74(3) and 83(3) of the Convention.' ${ }^{34}$ Guyana's invitation to bilateral negotiations following Suriname's protests against the CGX announcements was also held by the tribunal to be insufficient to discharge her obligations under the Convention. The tribunal then specified the precise steps that Guyana could have taken that would have been consistent with her obligations under the Convention and thus sufficient to discharge her duty to make every effort to reach a provisional agreement. These steps:

"[I]nclude (1) giving Suriname official and detailed notice of the planned activities, (2) seeking (the) cooperation of Suriname in undertaking the(se) activities, (3) of fering to share the results of the exploration and giving Suriname an opportunity to observe the activities, and (4) offering to share all the financial benefits received from the exploratory activities." 35

By providing this detailed exposition of the required notification, information-sharing, and consultation process that the interested states must enter into, the tribunal clearly established the legally authoritative standards of behaviour for any state finding itself in a similar situation where it is seeking to initiate exploration activities, either in respect of a transboundary deposit or overlapping area of continental shelf claims, similar to that found in the South China Sea today. Within this notification, information-sharing, and consultation process, step (3) is arguably unprecedented in its requirement to share the scientific information gathered from the exploration activities. The tribunal has also drawn from similar requirements in the marine scientific research regime established under Part XIII of the 1982 Convention. Article 248 of UNCLOS requires the researching state (or international organization) to provide, inter alia, the following information to the coastal state in whose EEZ, or on whose continental shelf, they want to conduct research: (a) the nature and objectives of the project; (b) the method and means to be used; (c) the precise geographical area in which the project is to be conducted; (d) the visiting dates of the vessels or the equipment being utilized; (e) the name of the sponsoring institution; and (f) the extent to which the coastal state can participate, or be represented in the project. The tribunal has undertaken to elaborate in remarkably precise terms the notification, information-sharing, and consultation process that any initiating and responding claimant states within a disputed maritime area must follow. Distilling the legal standards of behaviour required of all parties to such disputes, it is possible to establish in detail first, what is required of the state that is keen on initiating the exploration activities within the disputed maritime area and second, what is required of the state that is responding to the initial moves of the first state. These detailed procedural steps are as follows:

The initiating state must notify the other interested state(s) directly of its intentions vis-àvis the disputed maritime area concerned and in doing so pave the way for negotiations to begin in good faith towards a provisional arrangement pending further negotiations for a final maritime boundary agreement.

The responding state, being also under an obligation at all times to make every effort at securing a provisional arrangement allowing for exploration and eventually exploration to begin, must then begin to actively negotiate in good faith with the initiating state as to the modalities of the proposed exploration activities.

Once the negotiation offer is made by the initiating state, the responding state is precluded from undertaking any unilateral action that would jeopardize the chances of a provisional arrangement being concluded. This is especially pertinent in respect of any actions that could be viewed as a threat, or use, of force. During these negotiations, any exploration activities can

${ }^{34}$ Ibid., para. 477.

35 Ibid. 
only proceed with an assurance by the initiating state that the results of such activities will be shared with the responding state and its appointed personnel allowed to observe the conduct of such activities. The initiating state must also offer to share the financial benefits from such exploration activities and presumably also any exploitation arising therefrom, although this latter aspect of the requirement was not specified as such by the tribunal in the Guyana/Suriname award. Finally, the non-performance by either state party of any of the steps specified above for that state party is likely to result in a finding of a failure to meet that state party's obligations under the relevant UNCLOS Articles.

Having outlined and highlighted the procedural international legal developments that specify the rules of engagement between states on the related issues of common water bodies, shared natural resources and environmental protection, the following section will examine the institutional and jurisdictional issues arising from any attempt to challenge claimant state activities in the South China Sea.

\section{Challenging State-Sponsored Activities in the South China Sea using the 1982 UNCLOS}

On 22 January 2013, the Republic of the Philippines instituted compulsory arbitral proceedings against the People's Republic of China under Annex VII to the UNCLOS 'with respect to the dispute with China over the maritime jurisdiction of the Philippines in the West Philippine Sea.' ${ }^{36}$ In response, the Chinese government has released several official statements denying both the admissibility of the Philippine claims before this UNCLOS Annex VII arbitral tribunal and its jurisdiction to hear the Philippines claims, culminating in the recent release in December, 2014 of a 'Position Paper of the Government of the People's Republic of China on the Matter of Jurisdiction in the South China Sea Arbitration Initiated by the Republic of the Philippines', by the PRC's Ministry of Foreign Affairs, which, inter alia, re-states the official Chinese government position that 'the subject-matter of the arbitration is the territorial sovereignty over several maritime features in the South China Sea, which is beyond the scope of the Convention and does not concern the interpretation or application of the Convention., ${ }^{37}$

While awaiting the decision of the constituted arbitral tribunal on both the admissibility of this dispute and its own jurisdiction in this regard, it is worth pointing out that if the terms of the present and other related South China Sea disputes involving state activities on the insular formations and surrounding waters are re-characterized as disputes over environmental protection, then Article 297(1)(c) of UNCLOS provides that such disputes are subject to the compulsory (judicial) procedures entailing binding decisions, under Section 2 of Part XV of UNCLOS, if they involve an allegation, inter alia, 'that a coastal State has acted in contravention of specified international rules and standards for the protection and preservation of the marine environment which are applicable to the coastal State.'

Moreover, pursuant to Article 290(1), ITLOS also has the power to prescribe provisional measures where such measures are appropriate under the circumstances to prevent irreparable prejudice to the respective rights of the parties to the dispute or to prevent serious harm to the marine environment, pending the final decision'. (emphasis added) In order to grant a party provisional measures pending the constitution of an Annex VII arbitral tribunal under Article 290(5) of the Convention, ITLOS must be satisfied, first, that the arbitral tribunal to be constituted will have prima facie jurisdiction over the dispute, and second, that the urgency of the situation justifies the prescription of provisional measures at that stage. According to Wolfrum, the latter basis for any provisional measures application under Article 290

36 Note Verbale No. 13-0211, Philippines, Department of Foreign Affairs, 22 January 2013, http://www.dfa.gov.ph/index.php/west-philippine-sea-arbitration-updates>, visited on 27 April 2015.

${ }^{37}$ See http://www.fmprc.gov.cn/mfa_eng/zxxx 662805/t1217147.shtml, visited on 27 April 2015. 
emphasizes the importance of Part XII of UNCLOS on marine environmental protection. In this regard, he points out that Article 31(2) of the 1995 Fish Stocks Agreement provides that such provisional measures can also be prescribed to prevent damage to straddling or migratory fish stocks covered by this Agreement. He notes further that this additional legal basis for a provisional measures application is evidence of an intention of the UNCLOS states parties to allow the relevant tribunal or court to prescribe such measures on behalf of the international community of states, as opposed to only those states whose individual legal interests/rights have been directly compromised. ${ }^{38}$

Tomka and Hernandez confirm that this latter legal basis for the prescription of provisional basis "is a Convention-specific aim relating purely to the marine environment." 39 They go on to suggest that "the use of the disjunctive 'or' in Article 290, paragraph 1, suggests that measures concerning the marine environment may be prescribed in addition to measures protecting the rights of the parties; these objectives need not necessarily exclude one another." ${ }^{40}$ Mensah, for example, notes that the ICJ could also prescribe provisional measures to prevent serious harm to the environment. ${ }^{41}$ While this may be the case, it is submitted here that within the ICJ context, this remedy can only be invoked in relation to serious harm caused to the territorial and maritime jurisdiction zones of a coastal state, rather than areas beyond national jurisdiction, as Article 41(1) of the ICJ Statute provides that the Court with the power to prescribe such provisional measures only "to preserve the respective rights of either party", rather than on behalf of the international community of states, as Wolfrum envisages in relation to Article 290 of UNCLOS (above).

This brings us to what Tomka and Hernandez observe is the more delicate question namely:

"whether the preservation of the marine environment may be justified not only in the interest of a party to a specific dispute, but also in regard to a more general interest. Thus far, such measures have always been requested from the Tribunal by one of the parties to a dispute, although it bears noting that the parties have also suggested or claimed that the measures requested are justified in the general interest." 42

Examples of the invocation of these related but also separate legal bases for provisional measures under the 1982 UNCLOS are considered next, beginning with the Southern Bluefin Tuna cases (1999), followed by the MOX Plant (2001) and Land Reclamation (2003) cases.

\section{International Case Law on Provisional Measures under Article 290 of UNCLOS}

In the Southern Bluefin Tuna Cases (New Zealand \& Australia v Japan) (1999) ${ }^{43}$ both Australia and New Zealand requested provisional measures by ITLOS, contending, inter alia, that Japan had failed to cooperate in the conservation of the southern bluefin tuna (SBT) stock by unilaterally implementing an experimental fishing programme, thereby violating their rights under articles 64 and 116 to 119 of the Convention. ${ }^{44}$ Moreover, any further catches of SBT,

${ }^{38}$ R. Wolfrum, 'Provisional Measures of the International Tribunal on the Law of the Sea', in P. C. Rao and R. Khan (eds.), The International Tribunal for the Law of the Sea: Law and Practice (Kluwer, Alphen aan den Rijn, 2001) p. 176.

${ }^{39}$ P. Tomka and G. I. Hernandez, 'Provisional measures in the International Tribunal for the Law of the Sea', in H. P. Hestermeyer et al. (eds.), Coexistence, Cooperation and Solidarity: Liber Amicorum Rudiger Wolfrum, Vol.2 (Brill, Leiden 2011) 1763-1785, at 1783.

${ }^{40}$ Ibid.

${ }^{41}$ T. A. Mensah, 'Provisional Measures in the ITLOS', 43 Heidelberg Journal of International Law (2002) p. 46. ${ }_{42}$ Tomka and Hernandez, supra.note 36 , at 1783-1784.

43 ITLOS Order, $27 \quad$ September https://www.itlos.org/fileadmin/itlos/documents/cases/case_no_3_4/Order.27.08.99.E.pdf >, visited on 27 April 2015.

${ }^{44}$ Ibid., para. 68. 
pending the hearing of the matter by an arbitral tribunal, would cause immediate harm to their rights. ${ }^{45}$ In response to the claims by these two states and Japanese objections to its jurisdiction, the Tribunal first noted that the conservation of the living resources of the sea is "an element of the protection and preservation of the marine environment", ${ }^{46}$ thereby fulfilling both criteria for the prescription of ITLOS provisional measures. The Tribunal then held that, regardless of the fact that it could not conclusively assess the scientific evidence presented by the parties, provisional measures were warranted as a matter of urgency to preserve the rights of the parties and to avert further deterioration of the SBT stock. ${ }^{47}$ The Tribunal thus prescribed an Order providing, inter alia, that:

“(d) Australia, Japan and New Zealand shall each refrain from conducting an experimental fishing programme involving the taking of a catch of southern bluefin tuna, except with the agreement of the other parties...; (e) Australia, Japan and New Zealand should resume negotiations without delay with a view to reaching agreement on measures for the conservation and management of southern bluefin tuna; (and) (f) Australia, Japan and New Zealand should make further efforts to reach agreement with other States and fishing entities engaged in fishing for southern bluefin tuna, with a view to ensuring conservation and promoting the objective of optimum utilization of the stock." 48

Perhaps the most comprehensive statement of claims relating to possible harm to the rights of a state party, as well as the wider marine environment, such that provisional measures were merited, occurred in the MOX Plant case (Eire v UK) $(2001)^{49}$ where Ireland claimed, inter alia, that the United Kingdom has breached its obligations under Articles 123 and 197 of UNCLOS in relation to the authorisation of the MOX plant, and has failed to cooperate with Ireland in the protection of the marine environment of the Irish Sea by refusing to share information with Ireland and/or refusing to carry out a proper environmental assessment of the impacts on the marine environment of the MOX plant and associated activities and/or proceeding to authorise the operation of the MOX plant whilst proceedings relating to the settlement of a dispute on access to information were still pending. ${ }^{50}$ Indeed, Barboza lauds the Tribunal for having taken a "highly preventive" and "cautious" approach in the MOX Plant case.${ }^{51}$ However, Tomka and Hernandez suggest that he may have overreached in claiming that the Tribunal's order on the prevention of harm to the marine environment embodies a community interest, as Ireland had invoked the protection of the environment in Article 290(1), as its own right. ${ }^{52}$ In any case, responding to these statements of claim by Ireland and the UK objections to them, the ITLOS unanimously prescribed the following provisional measure under Article 290, paragraph 5, of the Convention:

"Ireland and the United Kingdom shall cooperate and shall, for this purpose, enter into consultations forthwith in order to:

(a) exchange further information with regard to possible consequences for the Irish Sea arising out of the commissioning of the MOX plant;

(b) monitor risks or the effects of the operation of the MOX plant for the Irish Sea;

${ }^{45}$ Ibid., para.69.

${ }^{46}$ Ibid., para. 70.

${ }^{47}$ Ibid., para. 80.

${ }^{48}$ Ibid., para. 90(1)(d), (e) and (f)

49 ITLOS Order, 3 December,

<https://www.itlos.org/fileadmin/itlos/documents/cases/case_no_10/Order.03.12.01.E.pdf>, visited on 27 April 2015.

${ }^{50}$ Ibid., para.26.

${ }^{51}$ J. Barboza, 'Provisional Measures, or the Dangers of being Too Exceptional', in T. M. Ndiaye, R. Wolfrum, and C. Kojima (eds.), Law of the Sea, Environmental Law and Settlement of Disputes: Liber Amicorum Judge Thomas A. Mensah, Martinus Nijhoff,, Leiden 2007) pp. 143, 149-150.

${ }^{52}$ Tomka and Hernandez, supra note 36, ???? 
(c) devise, as appropriate, measures to prevent pollution of the marine environment which might result from the operation of the MOX plant." 53

Finally, in its request for provisional measures in the Land Reclamation case (Malaysia v Singapore) (2003) ${ }^{54}$ Malaysia stated that the rights which it seeks to preserve by the grant of provisional measures are those relating to the preservation of the marine and coastal environment and the preservation of its rights to maritime access to its coastline, in particular via the eastern entrance of the Straits of Johor, and claimed that these rights are guaranteed by the provisions of the Convention. ${ }^{55}$ In response to these claims by Malaysia, the ITLOS Order on Provisional Measures stated as follows:

"Considering that, given the possible implications of land reclamation on the marine environment, prudence and caution require that Malaysia and Singapore establish mechanisms for exchanging information and assessing the risks or effects of land reclamation works and devising ways to deal with them in the areas concerned..."56

Tomka and Hernandez thus conclude that "(i)t remains an open question whether the Tribunal will, when faced with a request for provisional measures by a party which does not invoke a general interest, go beyond such a request in ordering such provisional measures as to preserve the general interest." 57

\section{Conclusions}

There are three main types of activities within the South China Sea that are increasingly becoming flashpoints for possible wider and more serious conflicts between the littoral states of the region. These are first, the land reclamation and other activities on various insular formations in the South China Sea; second, the award of concessions for offshore hydrocarbon development in disputed continental shelf areas; and third, the permitting of fishery activities in the maritime jurisdiction zones, especially within the overlapping 200nm Exclusive Economic Zones (EEZs) from both mainland and insular coastlines in the South China Sea.

This survey of the international law of shared natural resources and international environmental law has shown that it is possible to distil a set of procedural obligations in relation to these activities. The procedural obligations elaborated within relevant international case law and multilateral conventions can be summarized as follows: first, notification of any planned activities to all interested states in the region; second, information-sharing between all claimant states, including information gathered during the EIA to be conducted prior to the activity being undertaken and subsequent environmental monitoring exercises; third, consultation with other claimant states as to whether and how their claimed rights or interests in the proposed activities can be protected; and finally, meaningful negotiations between these states as to how any disputes as to the relative rights and obligations of all the claimant states in relation to these activities can be resolved. The continuing difficulty faced by the claimant states in the South China Sea is in agreeing the appropriate international judicial forum in which these claims can be resolved. While the dispute settlement provisions of Part XV, and the possibility of provisional measures under Article 290 of UNCLOS have been canvassed here,

${ }^{53}$ ITLOS Order 2001 supra note 46, para. 89(1)

$\begin{array}{rrrrr}54 & \text { ITLOS } & \text { Order, } & 8 & \text { October }\end{array}$ <https://www.itlos.org/fileadmin/itlos/documents/cases/case_no_12/Order.08.10.03.E.pdf>, visited on 27 April 2015.

${ }^{55}$ Ibid., para.61.

56 Ibid., para.99.

${ }^{57}$ Tomka and Hernandez, supra note 36 , at 1784 , text to fn.92. 
it remains to be seen whether they will be successfully utilised in the future for the international legal resolution of the South China Sea disputes. 